\title{
Clinical Evaluation of Composite Resin Restorations in Posterior Teeth
}

\section{Avaliação Clínica de Restaurações de Resina Composta em Dentes Posteriores}

\author{
Matheus Bruno Costa*a; Erika Terumi Tomisaki ${ }^{\mathrm{b}}$; Daiane Cristina Mendonça dos Santos ${ }^{\mathrm{c}}$; Márcio Grama Hoeppnerc; \\ Sueli de Almeida Cardoso ${ }^{\mathrm{d}}$
}

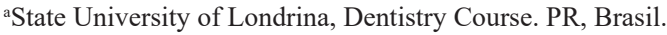 \\ ${ }^{\mathrm{b} S t a t e}$ University of Londrina, Dentistry Residency Program, Radiology \& Dental Imaging Área. PR, Brasil. \\ 'UUniversity of Londrina, Health Sciences Center. PR, Brasil. \\ dState University of Londrina. Departament of Restorative Dentistry. PR, Brasil. \\ *E-mail: matheusbc1009@gmail.com \\ Recebido em: 31/08/2020 \\ Aprovado em: 14/12/2020
}

\begin{abstract}
Factors such as aesthetics and adhesion to dental substrates have consolidated composite resin as a restorative material for posterior teeth, however, the performance is unsatisfactory regarding the longevity of these restorations. The purpose of this retrospective cross-sectional observational study was to evaluate the reasons that resulted in failure of class I and II Black composite resin restorations, performed by undergraduate dental students at the State University of Londrina. The patients were selected from the research of the medical charts filed at the University Dental Clinic's Screening Department. The restorations were evaluated by two calibrated dentists. The data collected were tabulated and analyzed using descriptive statistics, function Cont IF. Of the 261 class I and II restorations evaluated, $150(57.5 \%)$ were in need of replacement. The main causes of failure of class I and II restorations were secondary caries (46.7\%), followed by fracture (19.3\%) and loss of marginal adaptation (16.7\%). Of all the restorations made by the $3^{\text {rd }}$ grade students, $68.4 \%$ failed, $57.4 \%$ performed by the $4^{\text {th }}$ grade students and $53.9 \%$ of the $5^{\text {th }}$ grade students. Based on the results, it is concluded that the main reasons for restorations failure were secondary caries, fracture and loss of marginal adaptation according to the evaluation criteria. Restorations performed by students in the $3^{\text {rd }}$ grade showed a higher percentage of failures compared to those performed by students in the $4^{\text {th }}$ and $5^{\text {th }}$ grades.
\end{abstract}

Keywords: Permanent Dental Restoration. Composite Resins. Dental Restoration Failure.

\section{Resumo}

Fatores como estética e adesão aos substratos dentários têm consolidado a resina composta como material restaurador para dentes posteriores, entretanto, o desempenho mostra-se insatisfatório em relação a longevidade destas restaurações. O objetivo desse estudo observacional transversal retrospectivo foi avaliar as razões que resultaram em falhas das restaurações de resina composta de classe I e II de Black, realizadas por alunos de graduação em Odontologia da Universidade Estadual de Londrina. Os pacientes foram selecionados a partir da pesquisa dos prontuários arquivados no Setor de Triagem da Clínica Odontológica Universitária. As restaurações foram avaliadas por dois avaliadores, cirurgiões-dentistas, calibrados. Os dados coletados foram tabulados e analisados por meio de estatística descritiva, função Cont SE. Das 261 restaurações classes I e II avaliadas, 150 (57,5\%) apresentavam-se com necessidade de substituição. As principais causas de falhas das restaurações classes I e II foram: cárie secundária (46,7\%), seguido de fratura (19,3\%) e perda de integridade marginal (16,7\%). Dentre as restaurações realizadas por alunos da $3^{a}$ série e avaliadas, $68,4 \%$ falharam, da $4^{a}$ série $57,4 \%$ e da $5^{a}$ série $53,9 \%$. Com base nos resultados, conclui-se que as principais razões de falha das restaurações foram cárie secundária, fratura e perda de integridade marginal, de acordo com os critérios de avaliação. As restaurações realizadas por alunos da $3^{a}$ série apresentaram maior percentual de falhas, comparadas as realizadas pelos alunos da $4^{a}$ e $5^{a}$ séries.

Palavras-chave: Restauração Dentária Permanente. Resinas Compostas. Falha de Restauração Dentária.

\section{Introduction}

Aesthetics, the possibility of adhesion to dental substrates, the remaining dental structure reinforcement, low cost in relation to indirect procedures and improvements in physical properties have consolidated the composite resins (CR) as a material for the posterior teeth direct restoration ${ }^{1-3}$ compared to the silver amalgam clinical characteristics. However, posterior tooth $\mathrm{CR}$ restorations have shown more unsatisfactory performance ${ }^{4}$, which shows the importance of the dentist knowing the $\mathrm{CR}$ longevity as a restorative material and the reasons that can lead to failure.
The CR restorations longevity depends on factors such as the type of tooth and its position in the arch; the type, shape and extent of the cavity; the type of substrate on which CR will be inserted; oral conditions, the risk of caries, the patient's eating habits and bruxism habits; the knowledge and skill of the professional responsible for diagnosis, decision making, tooth preparation and restoration ${ }^{5-7}$.

The annual failure rate of CR restorations in posterior teeth is $1.8 \%$ over 5 years and $2.4 \%$ over 10 years, with secondary caries and fractures being the main reasons for CR restoration failure $^{8}$. These data express results of clinical studies where restorations were performed by experienced and trained 
dentists based on a rigorous and pre-established protocol ${ }^{9}$. However, the survival of posterior tooth CR restorations can be affected when performed by dental students at different learning and developing stages of their skills.

The objective of this retrospective cross-sectional observational study was to evaluate the reasons that resulted in failure of class I and II CR restorations of Black $^{10}$, performed by undergraduate dental students, based on the validated criteria of Ryge (modified United States Public Health Service - modified USPHS $)^{11}$.

\section{Material and Methods}

\subsection{Type of study and ethical considerations}

This was a retrospective cross-sectional observational study on the reasons why class I and II CR restorations performed by students of the Dentistry course at the State
University of Londrina (UEL) failed. The study was conducted after approval by the Research Ethics Committee involving Human Beings of UEL (CEP-UEL 1,607,965/2016), from February 2016 to December 2018. All the patients signed the Informed Consent Form.

\subsection{Patient selection and evaluation of restorations}

The patients were selected from the research of the medical records filed in the Screening Sector of the University Dental Clinic of UEL (COU/UEL). The restorations were evaluated by two evaluators, previously calibrated dentists (Kappa = 0.87), with the aid of an exploratory probe (No. 5, Golgran, São Caetano do Sul/Brazil) and a clinical mirror (No. 5, Golgran, São Caetano do Sul/Brazil), with clean, dry teeth and under direct artificial lighting, based on Ryge's criteria (modified USPHS) (Table 1) ${ }^{11}$.

Table 1 - Modified USPHS criteria

\begin{tabular}{|c|c|c|}
\hline \multirow{3}{*}{ Color match } & Alpha & The restoration seems to match the color and translucency of adjacent dental tissues. \\
\hline & Bravo & $\begin{array}{l}\text { The restoration does not match the color and translucency of adjacent dental tissues, but the incompatibility } \\
\text { is within the normal range of tooth shades, i.e., little changed. }\end{array}$ \\
\hline & Charlie & $\begin{array}{l}\text { The restoration does not match the shade and translucency of the adjacent teeth structure, and the gap is } \\
\text { outside the normal range of tooth shade and translucency, i.e., very altered. }\end{array}$ \\
\hline \multirow{3}{*}{$\begin{array}{c}\text { Marginal } \\
\text { discoloration }\end{array}$} & Alpha & $\begin{array}{l}\text { There is no visual evidence of marginal discoloration different from the restorative material shade and the } \\
\text { adjacent tooth structure shade. }\end{array}$ \\
\hline & Bravo & $\begin{array}{l}\text { There is visual evidence of marginal discoloration at the tooth structure junction and restoration. But the } \\
\text { discoloration has not penetrated along the restoration in a pulpal direction. Staining at the cavosurface angle } \\
<1 \mathrm{~mm}\end{array}$ \\
\hline & Charlie & $\begin{array}{l}\text { There is visual evidence of marginal discoloration at the tooth structure junction and the restoration that has } \\
\text { penetrated along the restoration in a pulpal direction. Staining along the restoration interface }\end{array}$ \\
\hline \multirow{3}{*}{$\begin{array}{l}\text { Secondary } \\
\text { caries }\end{array}$} & Alpha & $\begin{array}{l}\text { The restoration is a continuation of the existing anatomical shape adjacent to the restoration or is slightly } \\
\text { flattened. (absence of secondary caries) }\end{array}$ \\
\hline & Bravo & $\begin{array}{l}\text { There is visual evidence of discoloration remaining dark next to the restoration (presence of secondary } \\
\text { caries) }\end{array}$ \\
\hline & Charlie & -- \\
\hline \multirow{3}{*}{$\begin{array}{l}\text { Anatomic } \\
\text { form }\end{array}$} & Alpha & $\begin{array}{l}\text { The restoration is a continuation of the existing anatomical shape or is slightly flattened. It can be bypassed } \\
\text { and when the exploratory probe side is placed tangentially through the restoration, it must touch both sides, } \\
\text { i.e. the tooth surface and the restoration at the same time. }\end{array}$ \\
\hline & Bravo & $\begin{array}{l}\text { The surface concavity is evident. When the exploratory probe side is placed tangentially on the entire } \\
\text { restoration, it does not touch two opposite sides of the cavus angle at the same time, but the dentin or base } \\
\text { is not exposed. Poor contact point, cervical excess. }\end{array}$ \\
\hline & Charlie & There is a loss of restorative substance such that a concavity is evident and the base or dentin is exposed \\
\hline \multirow{3}{*}{$\begin{array}{l}\text { Marginal } \\
\text { adaptation }\end{array}$} & Alpha & $\begin{array}{l}\text { The exploratory probe does not grip when drawn over the restoration surface toward the tooth, there is no } \\
\text { visible slit, or that threads the exploratory probe, along the restoration periphery }\end{array}$ \\
\hline & Bravo & $\begin{array}{l}\text { There is visible evidence of a slit, which penetrates the exploratory probe, indicating that the restoration } \\
\text { edge does not closely adapt to the tooth structure. The dentin and base are not exposed and the restoration } \\
\text { is not movable }\end{array}$ \\
\hline & Charlie & The exploratory probe penetrates an extended gap to the dentin-enamel junction \\
\hline \multirow{3}{*}{$\begin{array}{l}\text { Surface } \\
\text { texture }\end{array}$} & Alpha & The surface texture similar to the polish enamel \\
\hline & Bravo & $\begin{array}{l}\text { Surface with a sandy texture or similar to a white stone surface or similar to a macroparticulated composite } \\
\text { resin }\end{array}$ \\
\hline & Charlie & $\begin{array}{l}\text { Surface is thick enough to inhibit the continuous circulation of an exploratory probe over the entire surface. } \\
\text { Probe does not slide }\end{array}$ \\
\hline \multirow{3}{*}{ Fracture } & Alpha & Restoration is intact and fully maintained \\
\hline & Bravo & Restoration is partially retained with some portion of the restoration still intact \\
\hline & Charlie & n completely absent \\
\hline
\end{tabular}




\subsection{Inclusion and exclusion criteria}

The following patients were included in the study: Class I and/or II CR restoration performed by third, fourth or fifth grade students of UEL Dentistry course, during the curricular clinical practice activities at COU/UEL, supervised by the professors; minimum age of 18 years; the restorative procedure correctly registered in their medical records (the student operator's grade, restoration date, type of cavity according to the faces involved, restorative material used, the restoration finishing and polishing); and with $\mathrm{CR}$ restoration with a life span in the oral cavity of at least 12 months, up to a maximum of 180 months.

Patients with CR restoration performed outside the COU/ UEL outpatient clinics or performed by professional dentist, patients special needs and with incomplete restorative procedure notes on the medical chart were excluded from the evaluation.

Data analysis

The data were collected was tabulated for descriptive analysis, according to the evaluation method used, function Cont IF.

\section{Results and Discussion}

$261 \mathrm{CR}$ restorations of 127 patients were evaluated, with a mean age of $53.5(+12.8), 88(69.3 \%)$ female and $39(30.7 \%)$ male. Sixty-nine $(26.4 \%)$ were class I restorations and 192 (73.6\%) class II restorations (Table 2).

Table 2 - Clinical evaluation of CR restorations according to Ryge's criteria ${ }^{11}$.

\begin{tabular}{|c|c|c|c|c|}
\hline \multirow[t]{2}{*}{ Criteria } & \multirow[t]{2}{*}{ Score } & $\begin{array}{l}\begin{array}{l}\text { Class I } \\
(n=69)\end{array}\end{array}$ & $\begin{array}{l}\text { Class II } \\
(\mathrm{n}=192)\end{array}$ & $\begin{array}{c}\text { Total } \\
(\mathrm{n}=\mathbf{2 6 1})\end{array}$ \\
\hline & & n (\%) & n (\%) & n (\%) \\
\hline \multirow{3}{*}{ Color match } & $\mathrm{A}$ & $52(75.4)$ & $105(54.7)$ & $157(60.2)$ \\
\hline & B & $14(20.3)$ & $59(30.7)$ & $73(28.0)$ \\
\hline & $\mathrm{C}$ & $3(4.3)$ & $15(7.8)$ & $18(6.9)$ \\
\hline \multirow{3}{*}{$\begin{array}{l}\text { Anatomic } \\
\text { form }\end{array}$} & $\mathrm{A}$ & $36(52.2)$ & $56(29.2)$ & $92(35.2)$ \\
\hline & $\mathrm{B}$ & $31(44.9)$ & $91(47.4)$ & $133(46.7)$ \\
\hline & $\mathrm{C}$ & $2(2.9)$ & $32(16.7)$ & $34(13.0)$ \\
\hline \multirow{2}{*}{$\begin{array}{l}\text { Secondary } \\
\text { caries }\end{array}$} & $\mathrm{A}$ & $60(87.0)$ & $113(58.9)$ & $193(73.9)$ \\
\hline & B & $9(13.0)$ & $66(34.4)$ & $75(28.7)$ \\
\hline \multirow{3}{*}{$\begin{array}{c}\text { Marginal } \\
\text { discoloration }\end{array}$} & $\mathrm{A}$ & $36(52.2)$ & $55(28.6)$ & $91(34.9)$ \\
\hline & $\mathrm{B}$ & $29(42.0)$ & $102(53.1)$ & $131(50.2)$ \\
\hline & $\mathrm{C}$ & $4(5.8)$ & $22(11.5)$ & $26(10.0)$ \\
\hline \multirow{3}{*}{ Fracture } & $\mathrm{A}$ & $61(88.4)$ & $155(80.7)$ & $216(82.8)$ \\
\hline & $\mathrm{B}$ & $8(11.6)$ & $24(12.5)$ & $32(12.3)$ \\
\hline & $\mathrm{C}$ & $0(0.0)$ & $13(6.8)$ & $13(5.0)$ \\
\hline \multirow{3}{*}{$\begin{array}{c}\text { Marginal } \\
\text { adaptation }\end{array}$} & $\mathrm{A}$ & $37(53.6)$ & $59(30.7)$ & $96(36.8)$ \\
\hline & $\mathrm{B}$ & $28(40.6)$ & $85(44.3)$ & $113(43.3)$ \\
\hline & $\mathrm{C}$ & $4(5.8)$ & $35(18.2)$ & $39(14.9)$ \\
\hline \multirow{3}{*}{$\begin{array}{l}\text { Surface } \\
\text { texture }\end{array}$} & $\mathrm{A}$ & $28(40.6)$ & $40(20.8)$ & $68(26.1)$ \\
\hline & $\mathrm{B}$ & $33(47.8)$ & $96(50.0)$ & $129(49.4)$ \\
\hline & $\mathrm{C}$ & $8(11.6)$ & $43(22.4)$ & $51(19.5)$ \\
\hline
\end{tabular}

Source: The authors.

Of the total 261 restorations evaluated, 150 (57.5\%) were evaluated with failure. Of the 69 class I restorations evaluated, loss of marginal adaptation, secondary caries and fracture were the main reasons for failure of $26(37.7 \%)$ restorations. While of the 192 class II restorations, 124 (64.6\%) were indicated for replacement, failed mainly due to secondary caries, fracture, loss of marginal adaptation and surface texture (Table 3 ). Such high value that can be justified by the technical difficulty experienced by students in restoring the proximal face, a delicate stage of the restorative technique ${ }^{12}$. A similar result was found by Braga et al. ${ }^{13}$, where $60.2 \%$ of class II restorations presented failures, performed by 37 experienced professionals.

Table 3 - Clinical evaluation of class I and II CR restorations presenting failures, according to Ryge's criteria ${ }^{11}$.

\begin{tabular}{|c|c|c|c|}
\hline \multirow{2}{*}{ Criteria } & Class I & Class II & Total \\
\cline { 2 - 4 } & $\mathbf{n}(\mathbf{\%})$ & $\mathbf{n ~ ( \% )}$ & $\mathbf{n ~ ( \% )}$ \\
\hline Color match & $0(0.0)$ & $1(0.8)$ & $1(0.7)$ \\
\hline Anatomic form & $0(0.0)$ & $5(4.0)$ & $5(3.3)$ \\
\hline Secondary caries & $9(34.6)$ & $61(49.2)$ & $70(46.7)$ \\
\hline Marginal discoloration & $0(0.0)$ & $3(2.4)$ & $3(2.0)$ \\
\hline Fracture & $5(19.2)$ & $24(19.4)$ & $29(19.3)$ \\
\hline Marginal adaptation & $10(38.5)$ & $15(12.1)$ & $25(16.7)$ \\
\hline Surface texture & $2(7.7)$ & $15(12.1)$ & $17(11.3)$ \\
\hline Total & $26(100)$ & $124(100)$ & $150(100)$ \\
\hline
\end{tabular}

Source: The authors.

The main failures of CR restorations, regardless of cavity type, were secondary caries $(46.7 \%)$, restoration fracture $(19.3 \%)$ and loss of marginal adaptation (16.7\%) (Table 3 ). These results support the studies by Brunthaler et al. ${ }^{1}$, Braga et al. ${ }^{13}$, Collins et al. ${ }^{14}$, Burke et al. ${ }^{15}$, Opdam et al. ${ }^{16}$, Al-Samham et al. ${ }^{17}$ and Kubo ${ }^{18}$. However, Moura et al ${ }^{19}$ reported that,. when evaluating the clinical performance and failure motives of 25 class I and 61 class II CR restorations, there were no failures due to secondary caries. The authors attributed the results to the current concepts of secondary caries and the 3-year assessment time of the restorations, with secondary caries being the reason for CR restorations failure in assessment periods longer than 5 years. In the present study $\mathrm{CR}$ restorations were evaluated with a lifetime in the oral cavity from 12 to 180 months, i.e., from 1 to 15 years, higher assessment period than the study performed by Moura et al. ${ }^{19}$.

Secondary caries were the main factor for CR restorations failure, especially in class II cavities. In addition, the limited clinical experience presented by the students, in the formation and skills development phase ${ }^{12}$, class II restorations are more prone to secondary caries failure due to: the cavity extension, the quality and quantity of tooth enamel present in the cervical wall of the proximal cavity, the inadequate $\mathrm{CR}$ clinical indication as a restorative material, the quality of operating field isolation, the technical sensitivity of the adhesive systems, the volume of $\mathrm{CR}$ inserted, the $\mathrm{CR}$ behavior in relation to the photoactivation technique, the difficulty finishing and polishing the restoration ${ }^{1,2,7,19}$.

The restoration or tooth fracture also causes $\mathrm{RC}$ restorations failure in posterior teeth ${ }^{2,7,20,21}$. This study showed 
a high rate of failure by restorations fracture, as supported by studies by Moura et al. ${ }^{19}$ and Berwenger et al. ${ }^{22}$, where fractures were the main failure causes. These results can be attributed to parafunctional habits, patient occlusion and lack of occlusal adjustment at the end of the restoration ${ }^{7}$. Class II cavities showed a higher failure percentage per restoration fracture than class I restorations, a result that confirms the higher failure probability in larger restorations with a larger area extension. In addition, the involvement of the proximal face reduces the restoration longevity ${ }^{2}$.

It was observed, in this study, that loss of marginal adaptation had a percentage of failures almost as high as fractures, as in the studies of Moura et al. ${ }^{19}$ and Berwenger et $\mathrm{al}^{22}$. The loss of marginal adaptation is directly a consequence of the operator's ability to handle the materials and to develop the restorative technique ${ }^{22}$. It is noteworthy that clinical evidence of slit in the tooth restoration interface may contribute to the biofilm retention and, in the long run, marginal infiltration, dental sensitivity and secondary caries development ${ }^{19}$. Therefore, many restorations evaluated with secondary caries, if evaluated in a shorter period of time, would be scored as loss of marginal adaptation.

Among the 261 restorations evaluated, 38 (14.6\%) were performed by students in the $3^{\text {rd }}$ grade and $26(68.4 \%)$ of these presented failures. Students in the $4^{\text {th }}$ grade performed $108(41.4 \%)$ restorations and $62(57.4 \%)$ failed. While 115 $(44.1 \%)$ restorations were performed by $5^{\text {th }}$ grade students, 62 $(53.9 \%)$ failed (Table 4$)$.

Tabela 4 - Clinical evaluation of class I and II CR restorations presenting failures, according to Ryge's criteria ${ }^{11}$, per students'grade

\begin{tabular}{|c|c|c|c|c|c|c|}
\hline \multirow{3}{*}{ Criteria } & \multicolumn{2}{|c|}{$3^{\text {rd }}$ Grade } & \multicolumn{2}{|c|}{$4^{\text {th }}$ Grade } & \multicolumn{2}{|c|}{$5^{\text {th }}$ Grade } \\
\hline & Class I & Class II & Class I & Class II & Class I & Class II \\
\hline & n (\%) & n (\%) & n (\%) & n (\%) & n (\%) & n (\%) \\
\hline Color match & $0(0.0)$ & $1(4.2)$ & $0(0.0)$ & $0(0.0)$ & $0(0.0)$ & $0(0.0)$ \\
\hline Anatomic form & $0(0.0)$ & $1(4.2)$ & $0(0.0)$ & $2(4.0)$ & $0(0.0)$ & $2(4.0)$ \\
\hline Secondary caries & $1(50.0)$ & $11(45.8)$ & $2(16.7)$ & $27(54.0)$ & $6(50.0)$ & $23(46.0)$ \\
\hline Marginal discoloration & $0(0.0)$ & $0(0.0)$ & $0(0.0)$ & $3(6.0)$ & $0(0.0)$ & $0(0.0)$ \\
\hline Fracture & $0(0.0)$ & $3(12.5)$ & $0(0.0)$ & $11(22.0)$ & $5(41.7)$ & $10(20.0)$ \\
\hline Marginal adaptation & $1(50.0)$ & $7(29.1)$ & $9(75.0)$ & $3(6.0)$ & $0(0.0)$ & $5(10.0)$ \\
\hline Surface texture & $0(0.0)$ & $1(4.2)$ & $1(8.3)$ & $4(8.0)$ & $1(8.3)$ & $10(20.0)$ \\
\hline Total & $2(100)$ & $24(100)$ & $12(100)$ & $50(100)$ & $12(100)$ & $50(100)$ \\
\hline
\end{tabular}

Source: The authors.

The number of restorations performed by students in the $4^{\text {th }}$ and $5^{\text {th }}$ grades was higher than those performed by students in the $3^{\text {rd }}$ grade. This is justified by the increasing workload allocated to clinical activities for dental restorations in the respective students' grade levels. Regardless of grade, secondary caries were the cause with the highest percentage of failures in class II restorations, which corroborates the studies that refer to the procedure technical difficulties ${ }^{1,13-18}$, besides indicating fragility in the students' technical education. When compared to clinical evaluation studies of $\mathrm{CR}$ restorations performed by experienced and calibrated professionals ${ }^{3,14-16,20,21}$, this study showed a higher percentage of failures in the evaluated restorations, the possible cause being the difference in experience between the operators.

The results of this study indicated a low percentage of restorations replacement by color match, anatomical form and marginal discoloration. Regarding the anatomical form, it may be that the most severe cases already presented secondary caries, making this the main reason evaluated for replacement. While color match and marginal discoloration are not aesthetically relevant factors that may indicate restoration failure in posterior teeth and, consequently, their replacement, they can be remedied by repolishing the restoration.

\section{Conclusion}

Based on the results, it is concluded that class II CR restorations failed more than class I restorations, with secondary caries, fractures and loss of marginal adaptation being the main causes according to the evaluation criteria. Restorations performed by students in the $3^{\text {rd }}$ grade showed a higher percentage of failures compared to those performed by students in the $4^{\text {th }}$ and $5^{\text {th }}$ grades.

\section{References}

1. Brunthaler A, König F, Lucas T, Sperr W, Schedle A. Longevity of direct resin composite restorations in posterior teeth. Clin Oral Investig 2003;7(2):63-70. doi: https://doi. org/10.1007/s00784-003-0206-7.

2. Rodolpho PAR, Cenci MS, Donassollo TA, Loguércio AD, Demarco FF. A clinical evaluation of posterior composite restoration: 17-year findings. J Dent 2006;34(7):427-35. doi: https://doi.org/10.1016/j.jdent.2005.09.006.

3. Rodolpho PAR, Donassollo TA, Cenci MS, Loguércio AD, Moraes RR, Bronkhorst EM, et al. 22-Year clinical evaluation of the performance of two posterior composites with different filler characteristics. Dent Materials 2011;27(10):955-63. doi: https://doi.org/10.1016/j.dental.2011.06.001.

4. Bernardo M, Luis H, Martin MD, Leroux BG, Rue T, Leitão $\mathrm{J}$, et al. Survival and reasons for failure of amalgam versus composite posterior restorations placed in a randomized clinical trial. J Am Dent Assoc 2007;138(6):775-83. doi: 
https://doi.org/10.14219/jada.archive.2007.0265.

5. Opdam NJ, Bronkhorst EM, Loomans BA, Huysmans MC 12-year survival of composite vs. amalgam restorations. J Dent Res 2010;89(10):1063-7. doi: https://doi. org/10.1177/0022034510376071.

6. Opdam NJ, Bronkhorst EM, Roeters JM, Loomans BA. Longevity and reasons for failure of sandwich and totaletch posterior composite resin restorations. J Adhes Dent 2007;9(5):469-75.

7. Demarco FF, Corrêa MB, Cenci MS, Moraes RR, Opdam NJ. Longevity of posterior composite restorations: Not only a matter of materials. Dent Materials 2012;28(1):87-101. doi: https://doi.org/10.1016/j.dental.2011.09.003.

8. Opdam NJ, Van de Sande FH, Bronkhorst E, Cenci MS, Bottenberg P, Pallesen U, et al. Longevity of posterior composite restorations: a systematic review and metaanalysis. J Dent Res 2014;93:943-9. doi: https://doi. org/10.1177/0022034514544217.

9. Opdam NJ, Loomans BA, Roeters FJ, Bronkhorst EM. Five-year clinical performance of posterior resin composite restorations placed by dental students. J Dent 2004;32(5):37983. doi: https://doi.org/10.1016/j.jdent.2004.02.005.

10. Black GV. Operative dentistry. Chicago: Medico Dental; 1908.

11. Ribeiro MDF, Pazinatto FB. Critérios clínicos para decisão entre substituição ou reparo de restaurações em resina composta - revisão de literatura. Rev Bras Odontol 2016;73(3):223-30. doi: http://dx.doi.org/10.18363/rbo. v73n3.p. 223

12. Paiva OS, Oliveira Filho SRS. Insucesso na escolha da matriz individual: Restauração de cavidade classe II extensa - relato de experiência. DêCiên Foco 2017;1(1):73-82.

13. Braga SEM, Vasconcelos BT, Macedo MRP, Martins VRG, Sobral MA. Reasons for placement and replacement of direct restorative materials in Brazil. Quint Int 2007;38(4):189-94.
14. Collins CJ, Bryant RW, Hodge KL. A clinical evaluation of posterior composite resin restorations: 8-year findings. J Dent 1998;26(4):311-7. doi: https://doi.org/10.1016/S03005712(97)00019-5.

15. Burke FJ, Wilson NH, Cheung SW, Mjör IA. Influence of patient factors on age of restorations at failure and reasons for their placement and replacement. J Dent 2011;29(5):317-24. doi: https://doi.org/10.1016/S0300-5712(01)00022-7.

16. Opdam NJ, Bronkhorst EM, Roeters JM, Loomans BA. A retrospective clinical study on longevity of posterior composite and amalgam restorations. Dent Mat 2007;23(1):28. doi: https://doi.org/10.1016/j.dental.2005.11.036.

17. Al-Samhan A, Al-Enezi H, Alomari Q. Clinical evaluation of posterior resin composite restorations placed by dental students of Kuwait University. Med Princ Practice 2010;19(4):299-304. doi: https://doi.org/10.1159/000312717.

18. Kubo S. Longevity of resin composite restorations. Japan Dent Scie Rev 2011;47(1):43-55. doi: https://doi.org/10.1016/j. jdsr.2010.05.002.

19. De Moura FRR, Romano AR, Lund RG, Evandro P, Júnior SAR, Demarco FF. Three-year clinical performance of composite restorations placed by undergraduate dental students. Braz Dent J 2011;22(2):111-6. doi: https://doi. org/10.1590/S0103-64402011000200004.

20. Opdam NJ, Bronkhorst EM, Loomans BA, Huymans MC. Longevity of repaired restorations: a practice based study. J Dent 2012;40(10):829-35. doi: https://doi.org/10.1016/j. jdent.2012.06.007.

21. Van Dijken JW, Pallesen U. Four-year clinical evaluation of Class II nano-hybrid resin composite restorations bonded with a one-step self-etch and a two-step etch-and-rinse adhesive. J Dent 2011;39(1):16-25. doi: https://doi.org/10.1016/j. jdent.2010.09.006.

22. Berwanger C, Totti M, Richter VP, Coelho-de-Souza FH, Thomé T. Avaliação clínica retrospectiva de restaurações posteriores de resina composta. Rev Assoc Paul Cir Dent 2015; 69(4): 355-362. 